\title{
The presence of Lutzomyia longipalpis in a focus of American visceral leishmaniasis where the only proven vector is Lutzomyia cruzi. Corumbá, Mato Grosso do Sul State
}

\author{
Presença de Lutzomyia longipalpis em foco de leishmaniose visceral americana onde o vetor \\ provávelé somente o Lutzomyia cruzi. Corumbá, Mato Grosso do Sul
}

\author{
Soraya Oliveira dos Santos ${ }^{1}$, Jorge R. Arias², Marta de Paiva Hoffmann', Mara Beatriz Grotta Furlan', \\ Wilson Francisco Ferreira' ${ }^{1}$, Claucio Pereira ${ }^{1}$ and Lourival Ferreira ${ }^{1}$
}

\begin{abstract}
The present communication reports the presence of Lutzomyia longipalpis in Corumbá, Mato Grosso do Sul, where the principal vector is Lutzomyia cruzi.
\end{abstract}

Key-words: Sand flies. American visceral leishmaniasis.

Resumo A presente comunicação relata a presença do Lutzomyia longipalpis em Corumbá, Mato Grosso do Sul, onde o vetor principal é o Lutzomyia cruzi.

Palavras-chaves: Mosquito-palha. Leishmaniose visceral americana.

Since 1983, many scientists have shown interest in the epidemiology of american visceral leishmaniasis $(\mathrm{AVL})$ in Corumbá, since studies have not detected the presence of Lutzyomia longipalpis, the principal known vector of this disease in the Americas ${ }^{1}$.

From 1995 to 1998 the entomology team of the Regional Coordination for Mato Grosso do Sul has been systematically capturing sand flies, vectors of Leishmania chagasi. These collections resulted in the incrimination of Lutzomyia cruzi as the vector of AVL in the absence of Lu longipalpis in Corumbá4.

Because of this pecularity, and in order to obtain more information on the vector involved, intensified studies were carried out in the field ${ }^{5}$, and in the laboratory, by various groups of scientists ${ }^{2}$.

The DIVEP team (Division of Epidemiological and Environmental Surveillance) of the Mato Grosso do Sul (Health) Co-ordination, presented a project to study the habits of Lu cruzi to the Coreplan (Regional Planning Council) in 2001, which included two monthly 24-hour captures in residences, caves and surrounding areas, using CDC miniature light traps.

The phlebotomine sand flies were captured in twohour intervals noting the corresponding time period, mounted and identified per capture period (every 2 hours).

Following this separation, in processing the collected material from 17/07/2001 from a pig sty and a chickenhouse in the Cristo Redentor District of Corumbá, three male specimens of Lu longipalpis were identified from the 22:00 - 24:00 hour collection.

For some time we have discussed the possibility of finding this species in Corumbá since it is present in the surrounding municipalities of Miranda, Aquidauana and Anastacio, where Lu longipalpis is the principal vector of AVL. Although there is a natural barrier between these municipalities and Corumbá (the Paraguay River), it is important to note that progress, particularly in transportation, (railways and highways) include the completion of a bridge over this river, offering more rapid access to the city of Corumbá.

\footnotetext{
1. Coordenação Regional de Mato Grosso do Sul da Fundação Nacional de Saúde. 2. Organização Panamericana de Saúde, Campo Grande, MS. Research conducted with the support of Fundação Nacional de Saúde

Address to: Dra. Soraya Oliveira dos Santos. R. Belizário Lima 263, Centro. 79470-210 Campo Grande, MS .

Tel: 5567 321-3074, Fax: 5567 382-8790

e-mail: sorayasantos@hotmail.com

Recebido para publicação em 2/8/2002

Aceito em 24/7/2003
} 
The importance of detecting Lu longipalpis lies in the fact that this species is better adapted to the epidemiology of the diseases and widely distributed throughout the Country and present in areas where AVL is a constant concern of public health control programs such as those of Teresina (Piauí State), Belo
Horizonte (Minas Gerais State), Araçatuba (São Paulo State), São Luis (Maranhão State) and, Tres Lagoas in Mato Grosso do Sul State).

The presence of Lu longipalpis in this focus of AVL presents a new variable in the epidemiology of this disease in Corumbá.

\section{REFERENCES}

1. Arias JR, Beltrán F, Desjeux P, Walton B. Epidemiología y Control de las Leishmaniasis en las Américas, por país o territorio. OPS, Cuaderno Técnico 44, 1996.

2. Galati EAB, N VLB, Oshiro ET, Rego FA Jr. Nova espécie de Phlebotominae Lutzomyia corumbaensis, sp.n. (Diptera: Psychodidade) do complexo Lutzomyia cortelezzi. Revista Brasileira de Entomologia 33: 465-475, 1989.

3. Galati EAB, Rego FA Jr, Nunes VBL, Teruya E. Fauna flebotomínica do município de Corumbá, Mato Grosso do Sul. Brasil e descrição de Lutzomyia forattinii, sp.n. (Diptera: Psychodidae, Phlebotominae). Revista Brasileira de Entomologia 29: 261-266, 1985.
4. Santos SO, Arias JR, Ribeiro AA, Hoffmann MP, Freitas RA, Malacco MAF. Incrimination of Lutzomyia (Lutzomyia) cruzi as a vector of American Visceral Leishmaniasis. Medical and Veterinary Entomology 12:315-317, 1998.

5. Santos SO, Falcão AL, Brazil R. Behavior of the Lutzomyia (Lutzomyia) cruzi (Diptera: Psychodidae), vector of the American Visceral Leishmaniasis and other phlebotomines in Corumbá and Ladário, Mato Grosso do Sul, Brasil. I. Evaluation of peri and intra-domiciliary environments using CDC light traps. Poster in $3^{\text {rd }}$ International Symposium on Phlebotomine sandflies, Montpellier-France, 1999. 